\section{耍 Heighten Science \\ P U B L I C I T I O N S Corporation ISSN \\ 2576-9537}

\title{
Squamous cell carcinoma developed on neglected, mistreated and delayed diagnosed chronic venous leg ulcer
}

\author{
Laura Maria Curic* and Marino Cordellini \\ Department of Plastic Surgery, USL Umbria 1, Italy
}

\begin{abstract}
*Address for Correspondence: Laura Maria Curic Department of Plastic Surgery, USL Umbria 1, Italy, Email: lauracuric2004@yahoo.com

Submitted: 16 January 2019

Approved: 02 February 2019

Published: 04 February 2019
\end{abstract}

Copyright: ๑ 2019 Curic LM, et al. This is an open access article distributed under the Creative Commons Attribution License, which permits unrestricted use, distribution, and reproduction in any medium, provided the original work is properly cited

Keywords: Chronic venous leg ulcer; Malignant transformation; Squamous cell carcinoma

Check for updates

\section{Abstract}

Chronic venous leg ulcers (VLU), especially long-lasting non-healing ulcers, are among the risk factors for squamous cell carcinoma (SCC) with particularly aggressive behaviour. We present a case of a 71-year-old female patient with a relevant personal history of multiple SCC and basal cell carcinoma (BCC) excision and chronic venous insufficiency showing for about three years a ulcerated lesion located on the anteromedial distal third of the left leg non-responsive to specific treatment, which subsequently increased their size and merged. Biopsy sample was taken. Histopathology revealed a G2 SCC in all biopsy samples. After the staging, a left inguino-femoral lymphadenectomy and the excision were done. The treatment of bone exposure with a soleus muscle flap in the upper half of the defect and skin graft for all the defect and a specific oncologic treatment were proposed as possible curative solutions. Patients with chronic venous leg ulcers and clinically suspicious lesions should be evaluated for malignant transformation of the venous lesion. When diagnosed, malignancy complicating a chronic venous leg ulcer requires a resolute treatment as it may be fatal.

\section{Introduction}

It is well known that malignant lesions can arise on chronic ulcers and wounds [1] and may result either from malignant transformation, usually toward welldifferentiated SCC or may appear de novo and mimic the appearance of a chronic ulcer. BCC can arise but usually SCC is more frequent [2-6]. These lesions have a particularly aggressive behavior with high rates of metastases in regional lymph nodes, low five years survival rates and tendency to recurrence after treatment. Lesions located in the lower limbs seem to have a more aggressive behavior as compared to other anatomic sites in terms of metastasis, recurrence and survival rates [2-7]. We present a case of a delayed diagnosed SCC developed on a VLU. Neglect and inappropriate treatment of the primary lesion for about three years, in a patient with a relevant personal history of multiple SCC and BCC excision, are the most important contributing factors to the malignant transformation and extensive size of the lesion, making the reconstructive surgery the essential part of the treatment. This study aims to evaluate the use of soleus muscle flap as a surgical treatment of the leg bone exposure and to emphasize that early detection of these tumors as well as early surgical intervention could prevent tumor extension. Strategies are needed to improve patient compliances versus screening examinations [7].

\section{Case Report}

A non-smoking 71-year-old female patient with a relevant personal history of multiple SCC and BCC excision and chronic venous insufficiency, was admitted to our Department of Plastic Surgery for an extensive ulcerated lesion located on the 
anteromedial distal third of the left leg for about three years. The patient's medical history revealed that a year before admission she was subjected to excision of left leg G2 SCC with free margins at the histopathology examination. A prophylactic radiotherapy has been recommended. The patient refused and the wound was self-managed at home. About two month after surgery, the patient started to manifest progressive skin signs of recurrent venous ulcer non-responsive to specific local treatment, which subsequently increased in size. For this reason, the patient underwent a dermatological examination. Due to the failure to heal despite the surgery and specific local treatment for 2 month, a punch biopsy was performed, but the histopathological diagnosis was not possible because of the insufficient quantity of the bioptic material. On the occasion a radical excision of recurrence injury was recommended, that the patient refused again, continuing the local home self-managed treatment. After 6 month of local treatment with no favorable outcome, the radiotherapy treatment was done with the patient consensus. At the end of the radiotherapy treatment, the ulcerative lesion increased in size and the patient had complaints of intense pain with occasional bleeding and serous discharge from the lesion. After 2 month the patient decides to do a phlebological control. Given the condition (extensive ulcerated lesion $7 \times 10 \mathrm{~cm}$ with severe infection) a crop test was carried out, that showed the presence of multiple multi-resistance pathogens (Proteus mirabilis, Escherichia coli, Enterococcus faecalis, Corynebacterium striatum, Klebsiella oxytoca, Clostridium beijerinckii). The patient was hospitalized in the Infectious Diseases Department. During the admission period, the patient received systemic treatment with antibiotics, local treatment with antiseptics, wound debridement, perilesional antiseptics and topical corticosteroids, in order to prevent ulcer infection. After one month of treatment there was taken the decision to collect multiple biopsy samples. The histopathological aspect revealed a G2 SCC (Figure 1) in all biopsy samples.

After another month of treatment, clinical healing of infection was highlighted. In order to stage the lesion and schedule surgery, magnetic resonance imaging of the lower third of the left leg and chest abdominal pelvic TDM were done. Chest abdominal pelvic TDM showed the presence of a cluster of increased hypervascularized left inguinofemoral lymph nodes $(1,6 \times 2 \mathrm{~cm}$ the larger). The magnetic resonance imaging, being done without contrast, didn't show signs of relapse of the disease. The patient has come to our attention three years after the onset of pathology. A radical left inguinofemoral lymphadenectomy was performed by the general surgeon. We performed a complete excision of the ulcerated lesion with a negative extemporaneous exam (Figure 2) and the treatment of bone exposure with a local muscle flap (soleus) in the upper half of the defect and skin graft for all the defect. At discharge, the

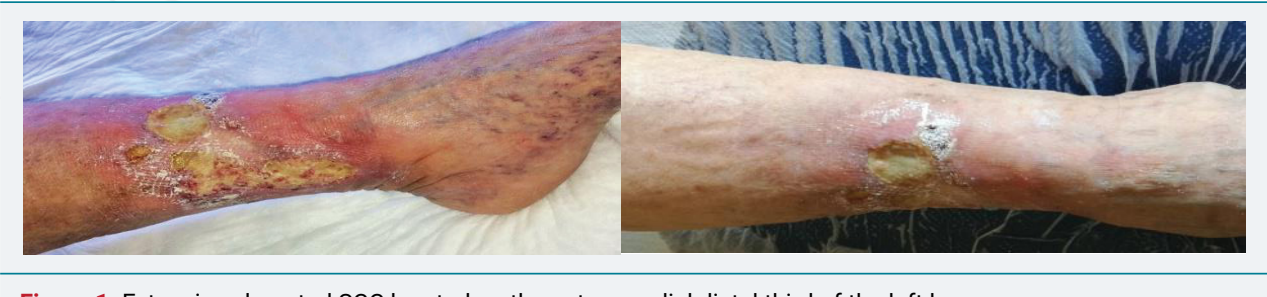

Figure 1: Extensive ulcerated SCC located on the anteromedial distal third of the left leg.

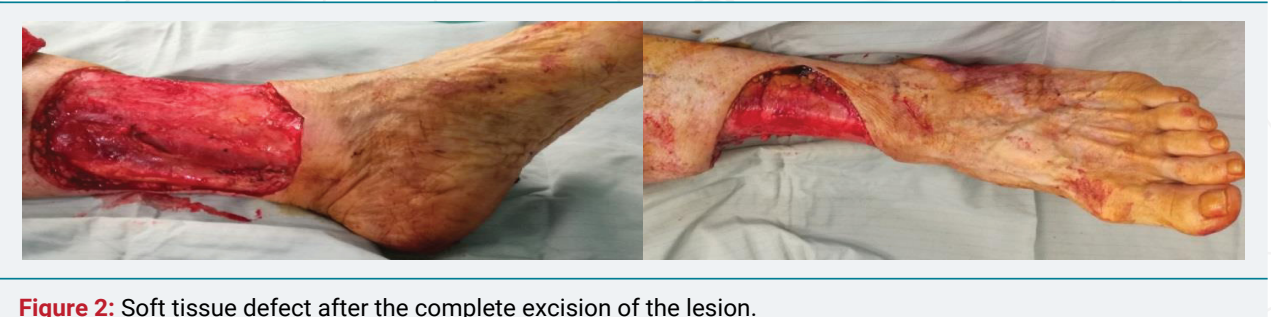

Figure 2: Soft tissue defect after the complete excision of the lesion. 
diagnosis was squamous cell carcinoma stage II - T3N1M0G2. The patient was referred to the Department of Oncology for specific oncologic treatment. In the shortterm postoperative evaluation, the healing was excellent without flap suffering and the skin graft was completely integrated. One year after surgery the walking ability was maintained, but there was partial loss of limb strength. We consider the aesthetic result perfectly acceptable with respect to other procedures within the reconstructive surgery arsenal (Figure 3A,B).

\section{Discussion}

VLU, especially long-lasting non-healing ulcers, are among the risk factors for SCC. Malignant transformation is rare and under-recognized, resulting in a delay in diagnosis and inadequate or reluctance to specific treatment of the primary lesion applied for a period exceeding three years [2-5]. In the last 20 years, various studies have shown that chronic inflammatory processes provide favorable conditions for the onset and development of some malignant lesions [9-11]. In our patient, venous system failure prolonged calf ulceration and provided the optimal environment for the onset of chronic inflammation. The immune system cells present in a chronic inflammation area, create a local mutagenic microenvironment, through the synthesis and release of reactive oxygen and nitrites species $[12,13]$, that cause cellular DNA mutations or genetic changes, thus favoring the emergence of cancer cells [11]. Patients with chronic VLU, mainly those with long-standing evolution (in our case more than 3 years), must be closely monitored and checked periodically [14]. Clinically suspicious lesions, those that do not heal despite a correct therapeutic management or even worsen with treatment, those which, in evolution, change their clinical appearance (rolled margins, multiple coalescing ulcers, nodular changes and regional lymphadenopathy) should be promptly biopsie (biopsy at regular intervals) and the sample must be submitted to immunohistochemical examination because carcinomas may mimic granulation tissue and complicate venous ulcers [14-17]. When diagnosed, SCC merits a thoughtful and complete investigation, including the differentiation degree and staging. Resolute treatment is indicated as poorly differentiated tumors and some moderately differentiated tumors may be fatal [14]. The choice of the most appropriate reconstructive procedure should take into account several issues including the size of the wounds with internal hardware exposure, the possibility of soft tissue coverage with pedicled flaps, the availability of recipient vessels, general conditions of the patients (such as age, diabetes mellitus, smoking history), patients' preference and presence of a microsurgical team. The treatment of lower limb skin loss is a challenge for surgeons and often requires the assistance of specialized techniques of plastic surgery and microsurgery. The vascular conditions of the lower limb should be evaluated carefully because diseases affecting the microvasculature or vascular lesions may prevent apparently well-planned flaps. The use of skin grafts in these lesions is hampered by the scarce vascular bed and the poor granulation of

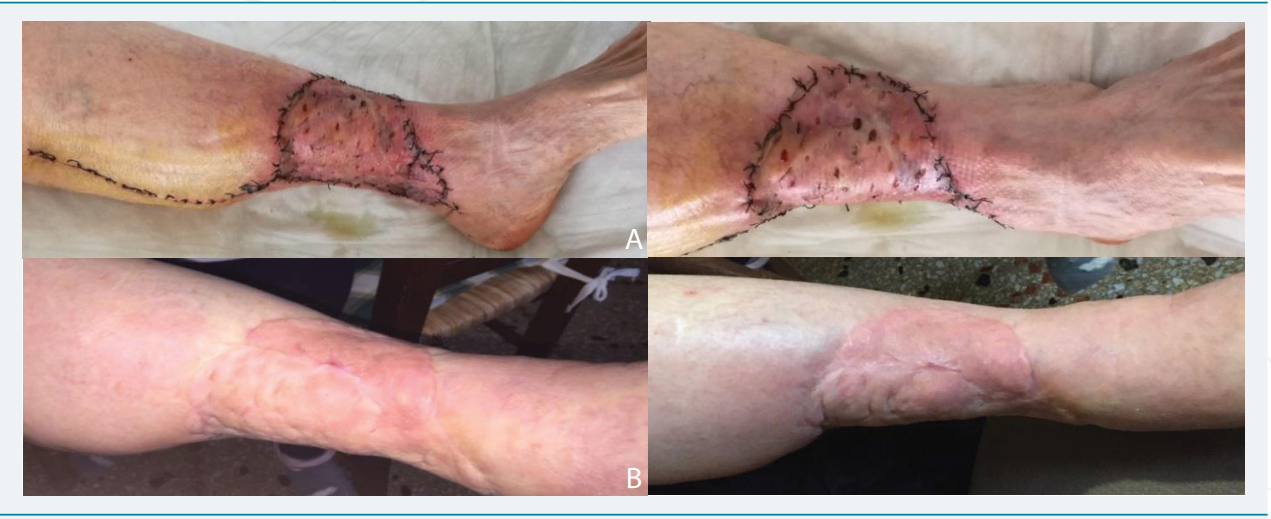

Figure 3: A) Result at 2 weeks. B) Result at 1 year. 
wounds, often associated with prolonged exposure of deep structures, such as bone, tendon and blood vessel, and may be exacerbated by infections, as osteomyelitis [18]. There are many pedicled flaps for soft tissue reconstruction in lower extremities (local fasciocutaneous flaps, the sural flap or reverse sural flap, the gastrocnemius flap, the saphenous fasciocutaneous flap, the soleus or hemisoleus flap, the lateral supramalleolar flap, the perforator-based propeller flap) but the selection of the the flaps depends on the avaibility of the donor sites, which are mainly located around the injured area [19-27]. Nowadays free-flap is the choice method to cover soft tissue defects in the distal third of the leg, but it has major disadvantages [28,29]. Microsurgery instruments should be made available, the surgeon should be familiar with this method and recipient site should have suitable vessels-which are serious problems in many cases. The propeller flap is well documented as an option for the majority of coverage in the lower limb, particularly below the knee, with the peroneal and posterior tibial artery perforators being commonly used [22,23], but a recent literature review reports up to $16 \%$ of flaps suffering partial necrosis, with a third of them involving the whole flap, especially in patients with venous insufficiency [23]. The unique anatomic features of the soleus (the longest and the largest one below the knee, binary blood flow, good arc of rotation) have made it a suitable muscle to repair soft tissue defects in the proximal and middle third of the leg, being the most used, usually individually [27]. Muscle flaps have limited use in the distal end of the leg and are unsafe when compared with those for the proximal and middle thirds of the leg. We used the soleus flap with good resolution in our patient, in the upper distal third defect. Reverse soleus flap has been used in the past ,but it seems that the results have been subject to overstatement and it must be noted that the anatomy of the soleus, nourished by instable perforating arteries in the distal third, disqualifies its success in all cases [30-32]. We know that muscle transposition improves the blood supply to the receiving region, contributing significantly to the treatment of infection and promoting the healing process of tissues, including bone. This method allows the primary treatment of skin defects with bone exposure. Therefore, it is indicated as an aid in the treatment of venous ulcers, fractures, osteomyelitis and pseudoarthrosis with exposed bone or scar adherent to the bone [33-36]. Knowledge of anatomy and surgical technique make the transposition of these muscles a feasible procedure for surgeon, who, with practice, starts to spend less time in the procedure than with other techniques, such as microsurgical flaps.

\section{Conclusion}

SCC arising in the context of a VLU has a particularly aggressive behavior. Patients with VLU and clinically suspicious lesions should be evaluated for malignant transformation of the venous lesion. Early surgical intervention could prevent tumor extension. Strategies to improve public awareness regarding the signs of skin cancer and careful screening examinations by all physicians as well as the necessity of an early surgical treatment are therefore recommended [8].

\section{References}

1. Pekarek B, Buck S, Osher L. A comprehensive review on Marjolin's ulcers: diagnosis and treatment. J Am Col Certif Wound Spec, 2011; 3: 60-64. Ref.: https://goo.gl/jJuNTR

2. Celić D, Lipozenčić J, Ljubojević Hadžavdić S, Kanižaj Rajković J, Lončarić D, et al. A Giant Basal Cell Carcinoma Misdiagnosed and Mistreated as a Chronic Venous Ulcer. Acta Dermatovenerol Croat. 2016; 24: 296-298. Ref.: https://goo.gl/K9CVX9

3. Lestre S, Serrão V, João A, Lobo L, Apetato M. Giant basal cell carcinoma presenting as a chronic leg ulcer. Eur J Dermatol. 2010; 20: 227-228. Ref.: https://goo.gl/he79YU

4. Combemale P, Bousquet $\mathrm{M}$, Kanitakis J, Bernard P. Angiodermatology Group, French Society of Dermatology. Malignant transformation of leg ulcers: a retrospective study of 85 cases. J Eur Acad Dermatol Venereol. 2007; 21: 935-941. Ref.: https://goo.gl/XBeJd9 
5. Granel F, Barbaud A, Schmutz JL. Basal and squamous cell carcinoma associated with chronic venous leg ulcer. Int J Dermatol. 2001; 40: 539-540. Ref.: https://goo.gl/LW9DUa

6. Gosain A, Sanger JR, Yousif NJ, Matloub HS. Basal cell carcinoma of the lower leg occurring in association with chronic venous stasis. Ann Plast Surg. 1991; 26: 279-283. Ref.: https://goo.gl/ZWenRN

7. Cassarino DS, Derienzo DP, Barr RJ. Cutaneous squamous cell carcinoma: a comprehensive clinicopathologic classification - part two. J Cutan Pathol. 2006; 33: 261-279. Ref.: https://goo.gl/nS7U3D

8. Robson MC, Cooper DM, Aslam R, Gould LJ, Harding KG, et al. Guidelines for the treatment of venous ulcers. Wound Repair Regen. 2006; 14: 649-662. Ref.: https://goo.gl/o5L5m6

9. Lu H, Ouyang W, Huang C. Inflammation, a key event in cancer development. Mol Cancer Res. 2006; 4: 221-233. Ref.: https://goo.gl/Ef739V

10. Itzkowitz SH, Yio X. Inflammation and cancer. IV. Colorectal cancer in inflammatory bowel disease: the role of inflammation. Am J Physiol Gastrointest Liver Physiol. 2004; 287: G7-G17. Ref.: https://goo.gl/m1jacX

11. Coussens LM, Werb Z. Inflammation and cancer. Nature. 2002; 420: 860-867. Ref.: https://goo.gl/EGMHWW

12. Fulton AM, Loveless SE, Heppner GH. Mutagenic activity of tumor-associated macrophages in Salmonella typhimurium strains TA98 and TA100. Cancer Res. 1984; 44: 4308- 4311. Ref.: https://goo.gl/FaHCcP

13. Maeda $H$, Akaike $H$. Nitric oxide and oxygen radicals in infection, inflammation, and cancer Biochemistry (Mosc). 1998; 63: 854-865. Ref.: https://goo.gl/cyveJA

14. Sirbi AG, Florea M, Patrascu V, Rotaru M, Mogos DG, et al. Squamos cell carcinoma developed on chronic venous leg ulcer. Rom J Morphol Embryol. 2015; 56: 309-313 Ref.: https://goo.gl/EEH3kN

15. Senet $P$, Combemale $P$, Debure $C$, Baudot N, Machet $L$, et al. Malignancy and chronic leg ulcers: the value of systematic wound biopsies: a prospective, multicenter, cross-sectional study. Arch Dermatol. 2012;148: 704-708 Ref.: https://goo.gl/NA2m1i

16. Jankovic A, Binic I, Ljubenovic M. Basal cell carcinoma is not granulation tissue in the venous leg ulcer. Int J Low Extrem Wounds. 2008; 7: 182-184. Ref.: https://goo.gl/FZdL7r

17. Harris B, Eaglstein WH, Falanga V. Basal cell carcinoma arising in venous ulcers and mimicking granulation tissue. J Dermatol Surg Oncol. 1993;19: 150-152. Ref.: https://goo.gl/atDNt9

18. D'Avila F, Diogo F, D'Avila B, Arnaut M Jr. Use of local muscle flaps to cover leg bone exposures. Rev Col Bras Cir. 2014; 41. Ref.: https://goo.gl/KE68px

19. Filippini A, Zuccarini F, Di Paolantonio G, Valbonesi L, Guerra L, et al. The distal pedicle fasciocutaneous flaps of the leg. Analysis of 21 cases of lower limb reconstruction. Ann Ital Chir. 1995; 66: 479-484. Ref.: https://goo.gl/X1w8Jo

20. Vendramin FS. Retalho sural de fluxo reverso: 10 anos de experiência clínica e modificações. Ver Bras Cir Plást. 2012; 27: 309-315.

21. Hughes LA, Mahoney JL. Anatomic basis of local muscle flaps in the distal third of the leg. Plast Reconstr Surg. 1993; 92: 1144-1154. Ref.: https://goo.gl/tsu8uW

22. Gir P, Cheng A, Oni G, Mojallal A, Saint-Cyr M. Pedicled perforator (propeller) flaps in lower extremity defects: a systematic review. J Reconstr Microsurg. 2012; 28: 595-601. Ref.: https://goo.gl/rhbBAZ

23. Nelson JA, Fischer JP, Brazio PS, Kovach SJ, Rosson GD, et al. A review of propeller flaps for distal lower extremity soft tissue reconstruction: Is flap loss too high? Microsurgery. 2013; 33: 5785-86. Ref.: https://goo.gl/NfSYBJ

24. Buchner M, Zeifang F, Bernd L. Medial gastrocnemius muscle flap in limb-sparing surgery of malignant bone tumors of the proximal tibia: mid-term results in 25 patients. Ann Plast Surg. 2003 51: 266-272. Ref.: https://goo.gl/ECFLxB

25. Sundell B, Asko-Seljavaara S. Transposition of muscle flaps for covering exposed bone in the leg. Ann Chir Gynaecol. 1979; 68: 1-5. Ref.: https://goo.gl/KnmTEP

26. Magee WP Jr, Gilbert DA, Mclnnis WD. Extended muscle and musculocutaneous flaps. Clin Plast Surg. 1980; 7: 57-70. Ref.: https://goo.gl/iKb4Bf

27. Hallock GG. Getting the most from the soleus muscle. Ann Plast Surg. 1996; 36: 139-146. Ref.: https://goo.gl/ipyqAY 
28. Heller L, Levin LS. Lower extremity microvascular reconstruction. Plast Reconstr Surg. 2002; 108: 1029-1041. Ref.: https://goo.gl/7tzqzt

29. Pu LLQ, Medalie DA, Rosenblum WL, Lawrence SJ, Vasconez HC. Free tissue transfer to a difficult wound of the lower-extremity. Ann Plast Surg. 2004; 53: 222-228. Ref.: https://goo.gl/mwRk4K

30. Pu LLQ. Successful soft-tissue coverage of a tibial wound in the distal third of the leg with a medial hemisoleus muscle flap. Plast Reconstr Surg. 2005; 115: 245-251. Ref.: https://goo.gl/Td87YY

31. Pu LL. The reversed medial hemisoleus muscle flap and its role in reconstruction of an open tibial wound in the distal third of the leg. Ann Plast Surg. 2006; 56: 59-64. Ref.: https://goo.gl/4GUJZz

32. Pu LL. Further experience with the medial hemisoleus muscle flap for soft-tissue coverage of a tibial wound in the distal third of the leg. Plast Reconstr Surg. 2008; 121: 2024-2028. Ref.: https://goo.gl/pqDW4f

33. Arnold PG, Yugueros $P$, Hanssen AD. Muscle flaps in osteomyelitis of the lower extremity: a 20-year account. Plast Reconstr Surg. 1999; 104: 107-110. Ref.: https://goo.gl/VFZMuS

34. El-Khatib HA. The split peroneus muscle flap: a new flap for lower leg defects. J Plast Reconstr Aesthet Surg. 2007; 60: 898-903. Ref.: https://goo.gl/6ZNLPj

35. Rios-Luna A, Fahandezh-Saddi H, Villanueva-Martínez M, López AG. Pearls and tips in coverage of the tibia after a high energy trauma. Indian J Orthop. 2008; 42: 387-394. Ref.: https://goo.gl/qha1vW

36. Ahmad I, Akhtar S, Rashidi E, Khurram MF. Hemisoleus muscle flap in the reconstruction of exposed bonés in the lower limb J Wound Care. 2013; 22: 635: 638-40, 642. Ref.: https://goo.gl/iT7Zbb 